\title{
Effect of carob variety and roasting on the antioxidant capacity, and the phenolic and furanic contents of carob liquors
}

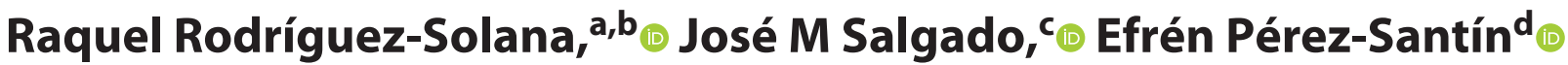 \\ and Anabela Romano ${ }^{\mathrm{a}, \mathrm{b}^{*}} \odot$
}

\begin{abstract}
BACKGROUND: The production of the traditional carob liquor from Algarve (Portugal) depends on numerous factors such as carob processing, variety and maceration conditions. An experimental design with 36 runs was created to evaluate the effect of the roasting temperature, particle size, variety of carob and time of maceration on several parameters of carob liquors as gallic acid and total phenolic content, the furanic composition (furfural and 5-(hydroxymethyl)furfural), browning index and in vitro antioxidant capacity.
\end{abstract}

RESULTS: The results revealed that carob variety was the independent variable with the greatest effect on antioxidant capacity, total phenolic and gallic acid content. In particular, AIDA liquors presented the highest results, mainly those prepared with unroasted carob. Meanwhile, Galhosa and Mulata liquors showed the greatest concentrations when the carob pulp was roasted at $150^{\circ} \mathrm{C}$. The furanic composition and browning index were greatly influenced by the carob roasting degree.

CONCLUSION: The levels of the main toxic furanics present in carob liquors, furfural and 5-(hydroxymethyl)furfural, suggest a safe consumption of these beverages even in samples of carobs with the maximum roasting degree. The smallest carob particle size favoured the highest phenolic extraction, while the longest maceration periods decreased the concentration of the toxic furanic compounds studied.

(c) 2018 Society of Chemical Industry

Supporting information may be found in the online version of this article.

Keywords: Ceratonia siliqua L.; maceration; roasting; phenolic compounds; furanic compounds; antioxidant capacity

\section{INTRODUCTION}

Ceratonia siliqua $\mathrm{L}$. is an evergreen tree widely cultivated in the whole Mediterranean basin and other Mediterranean-like regions. According to Food and Agriculture Organization of the United Nations statistics, since 2013 Portugal has positioned as the world leader in carob pod production (about $25 \%$ of total world production), the bean-like fruit of the C. siliqua. ${ }^{1}$

The carob fruit contains two major parts: the pulp (90\%) and the seeds $(10 \%){ }^{2}$ Carob pulp is considered a by-product of the seed industry and is commercialized in kibbles or powder (both roasted or unroasted). ${ }^{3-5}$ This part of the fruit has been widely used in the past as human food in times of scarcity or famine and in the diet of farm animals. ${ }^{6}$ Nowadays, global demand for natural and healthy foods is helping to drive a resurgence in carob consumption. Carob pulp is used as a cocoa replacer because of its similar aroma and the fact that it is caffeine and theobromine-free. In addition to these characteristics, the nutritional components such as important amino acids (aspartic and glutamic acids, alanine, leucine, etc), minerals $(\mathrm{K}, \mathrm{Ca}, \mathrm{Na} \text { and } \mathrm{Fe})^{7}$ and vitamins $(\mathrm{B} 3, \mathrm{~B} 6, \mathrm{~B} 9, \mathrm{C}, \mathrm{D}$ and $E)^{8}$ and other components as high levels of dietary fiber, phenolics (gallic acid (GA) as the major constituent) ${ }^{9}$ and sugars (mostly sucrose), ${ }^{10}$ make carob pulp an important component in different food preparations. Those include the elaboration of carob liqueurs in different countries comprising the main carob world producers e.g. licor de alfarroba (Portugal), licor de algarrobo (Spain) and liquore di carrubo (Italy). ${ }^{8,11}$ This type of liqueur occupies the top of production in Algarve, the largest carob producing region in Portugal. $^{12}$

The phenolic and antioxidant capacity of carob products depend mainly on the carob variety and technological factors associated to carob pulp processing. ${ }^{13}$ The carob roasting is a crucial factor

\footnotetext{
* Correspondence to: A Romano, Faculdade de Ciências e Tecnologia, Universidade do Algarve, Campus de Gambelas, Faro, Portugal. E-mail:aromano@ualg.pt

a Faculdade de Ciências e Tecnologia, Universidade do Algarve, Campus de Gambelas, Faro, Portugal

b Centro para os Recursos Biológicos e Alimentos Mediterrânicos (MeditBio), Universidade do Algarve, Faro, Portugal

c CEB-Centre of Biological Engineering, University of Minho, Campus de Gualtar, Braga, Portugal

d Graduate school of Engineering and Technology, International University of La Rioja (UNIR), Logroño, Spain
} 
and many chemical reactions occur during this process. On one side, sugar caramelisation and Maillard reaction favour the production of furans, esters and pyrroles that recall the aroma of cocoa. ${ }^{14}$ On the other hand, the release of phenolics takes place through the ruptured of high-molecular complexes from carob matrix or the partially degradation of phenolics which results in the production of different types of antioxidant molecules. ${ }^{15,16}$ The products of these chemical reactions, such as phenolic compounds and Maillard Reaction Products (MRPs), contribute to the antioxidant capacity and for the beneficial health properties of carob products. However, some intermediates of the Maillard reaction, such as 5-(hydroxymethyl)furfural (HMF) and furfural (F), have toxic effects. ${ }^{15}$ Although currently there are no legal limits established in liqueurs for both compounds, they do exist in other foods. According to the Brazilian legislation, the maximum level of $\mathrm{F}+\mathrm{HMF}$ allowed in cachaças is $5 \mathrm{mg} \mathrm{hL}^{-1}$ of anhydrous alcohol, ${ }^{17}$ and in the particular case of concentrated rectified grape must, EC Regulation No. $1493 / 99$ sets a limit of $25 \mathrm{mg} \mathrm{kg}^{-1}$ of total sugars for HMF. ${ }^{18}$

To date, several phenolic and/or antioxidant capacity studies have been done on carob pulp products from different countries: methanolic extracts from Portuguese varietal carobs including Aida, Galhosa and Mulata, ${ }^{13}$ mixture of Mulata and Galhosa supercritical carbon dioxide, ultrasound and conventional extracts; ${ }^{3,19}$ roasted and unroasted Turkish carob extracts; ${ }^{7,16}$ insoluble and soluble roasted Croatian carob fractions after gastrointestinal digestion; ${ }^{15}$ Greek carob pod crudes; ${ }^{20}$ extracts from German commercial carob products; ${ }^{9}$ Lebanese carob-based milk beverage using roasted and unroasted carob from varietal carob pods ${ }^{2}$ and methanol:acetone:water (30:30:40 v/v/v) extracts from Polish powdered carob pasta or carob flour. ${ }^{11}$ However, information on the factors which are likely to affect the liquor elaboration process is still missing. The objective of this study was to investigate the influence of carob pretreatment and maceration periods used in liquor elaboration on the phenolic and furanic composition, antioxidant properties and browning index of carob liquors using an experimental design, as well as optimizing the experimental conditions that results in the highest antioxidant activity and phenolic concentration with the minimum furanic content.

\section{MATERIALS AND METHODS} Materials

Ethanol, trichloroacetic acid (TCA), ascorbic acid, ABTS (2,2'-azino-bis(3-ethylbenzothiazoline-6-sulfonic acid) diammonium salt) tablets, potassium persulfate $\left(\mathrm{K}_{2} \mathrm{~S}_{2} \mathrm{O}_{8}\right)$ and tyrosol (2-(4-hydroxyphenyl)ethanol) were supplied by Sigma-Aldrich (Poole, UK). Folin-Ciocalteu's phenol reagent (FC reagent), sodium carbonate anhydrous $\left(\mathrm{Na}_{2} \mathrm{CO}_{3}\right)$ and ferric chloride $\left(\mathrm{FeCl}_{3}\right)$ were acquired from VWR (Leuven, Belgium). Potassium ferricyanide $\left[\mathrm{K}_{3}\left(\mathrm{Fe}(\mathrm{CN})_{6}\right)\right]$, trolox $[( \pm)-6$-hydroxy-2,5, 7,8-tetramethylchromane-2-carboxylic acid], 5-(hydroxymethyl) furfural and furfural were purchased from Acros organics (Geel, Belgium). Sodium di-hydrogen phosphate monohydrate, di-sodium hydrogen phosphate anhydrous and sodium chloride anhydrous were acquired from Panreac (Barcelona, Spain). Gallic acid (GA) was supplied by Fluka (Switzerland).

\section{Commercial and experimental carob samples and fig spirit Authenticated varietal carob pods}

The main Ceratonia siliqua L. varieties grown in Portugal, Galhosa, Mulata and AIDA, were selected to carried out the experiments.
These fruits were collected between August and September of 2016 from a germplasm repository in Tavira (DRAP Algarve, Portugal).

\section{Carob pod processing: roasted and unroasted carob kibbles and powder}

Carob kibbles were prepared by splitting and separating the seeds from the pods. Carob kibbles, $240 \mathrm{~g}$, were roasted for $40 \mathrm{~min}$ in an air forced draft oven at two different temperatures, 120 and $150^{\circ} \mathrm{C}$, while $120 \mathrm{~g}$ remained unroasted. These roasting temperatures were selected for being used in conventional roasting. ${ }^{15,16}$ Furthermore, half of the roasted $(120 \mathrm{~g})$ and unroasted $(60 \mathrm{~g})$ kibbles were crushed and sieved until all of the powder passed through the $0.212 \mathrm{~mm}$ sieve.

\section{Commercial carob powder}

A commercial roasted carob flour produced from plurivarietal Ceratonia siliqua L. fruits was provided by Industrial Farense LDA (Faro, Portugal), and was used as a control sample.

\section{Fig spirit}

Fig spirit (45\% v/v), purchased from Santa Catarina Cooperative (Fonte do Bispo, Portugal), was used in the maceration experiments as extractant.

\section{Production of carob liquor by maceration}

For the preparation of the experimental design, 36 experiments (Table 1), a total of $360 \mathrm{~g}$ of carob pulp of two different particles sizes (kibbles and flour), three different roasting degrees (unroasted, and roasted at 120 , and $150^{\circ} \mathrm{C}$ ), and three different carob varieties (AIDA, Galhosa and Mulata) were mixed in a proportion of $5 \%(\mathrm{w} / \mathrm{v})$ with the fig distillate $(45 \% \mathrm{v} / \mathrm{v}$; a total of $7.2 \mathrm{~L})$. Carob and distillate, were kept in contact for 1 or 3 weeks of maceration in topaz bottles $(125 \mathrm{~mL})$ in the dark at room temperature. Samples were shaken daily, filtered under vacuum and stored in the dark until analysis. All experiments were performed in duplicate.

\section{Identification and quantification of phenolic and furanic composition by HPLC-PDA analysis}

Carob liquors were filtered through $0.2 \mu \mathrm{m}$ pore cellulose acetate membrane (VWR international, USA) before the analysis. Due to the complexity of the carob liquor matrix, the HPLC method followed with slight modifications (different column temperature and different particle size of the column packed) belongs to an official method (COI/T.20/Doc No29) used in the identification of phenolic compounds in the complex matrix of olive oil. Briefly, $20 \mu \mathrm{L}$ of sample or standard were analysed using a HPLC-PDA system (Varian 920-LC) and a Kromasil $100 \AA$ pore size C18 column ( $250 \mathrm{~mm}$ length $\times 4.6 \mathrm{~mm}$ i.d. and $10 \mu \mathrm{m}$ of particle size). The solvent mixture system contained $0.2 \% \mathrm{H}_{3} \mathrm{PO}_{4}$ in water $(\mathrm{A})$, methanol (B) and acetonitrile (C) with a flow rate of $1 \mathrm{~mL} \mathrm{~min}^{-1}$.

Separation was achieved using a gradient flow as follows: 0 min$96 \%$ A, 2\% B and 2\% C; 40 min- $50 \%$ A, 25\% B and $25 \%$ C; 45 min- $40 \%$ A, 30\% B and 30\% C; 60 min- $0 \%$ A, 50\% B and $50 \%$ C; 70 min- $0 \%$ A, 50\% B and 50\% C; 72 min- $96 \%$ A, 2\% B and $2 \% \mathrm{C}$ and $82 \mathrm{~min}-96 \% \mathrm{~A}, 2 \% \mathrm{~B}$ and $2 \% \mathrm{C}$. Detection was carried out by using a photo-diode array detector at $280 \mathrm{~nm}$. Peak identification was based on the comparison of UV spectra and retention time with authentic standards. Tyrosol was used as 


\begin{tabular}{|c|c|c|c|c|c|c|c|c|c|c|c|}
\hline \multirow[b]{3}{*}{ Run } & \multicolumn{4}{|c|}{ Independent variables } & \multicolumn{7}{|c|}{ Dependent variables } \\
\hline & \multirow{2}{*}{$\begin{array}{l}\text { Particle } \\
\text { size }\end{array}$} & \multirow[b]{2}{*}{ Variety } & \multirow{2}{*}{$\begin{array}{c}\text { Roasting } \\
\text { temperature } \\
\left({ }^{\circ} \mathrm{C}\right)\end{array}$} & \multirow{2}{*}{$\begin{array}{l}\text { Maceration } \\
\text { time } \\
\text { (weeks) }\end{array}$} & \multirow[t]{2}{*}{ GA } & \multirow{2}{*}{$\frac{\mathrm{F}}{\mathrm{mg} \mathrm{L}^{-1}}$} & \multirow{2}{*}{ HMF } & \multirow[b]{2}{*}{$\mathrm{TPC}^{\mathrm{a}}$} & \multicolumn{2}{|c|}{$A C$} & \multirow{2}{*}{$\begin{array}{l}\text { Browning } \\
\text { Index }\end{array}$} \\
\hline & & & & & & & & & TEAC ${ }^{b}$ & FRAPC & \\
\hline 1 & Kibble & AIDA & - & 1 & 32.49 & 19.26 & $<\mathrm{LOD}$ & 460.52 & 3.94 & 6.09 & 0.95 \\
\hline 2 & Kibble & AIDA & - & 3 & 38.34 & 18.09 & $<\mathrm{LOD}$ & 558.00 & 5.36 & 6.35 & 1.07 \\
\hline 3 & Flour & AIDA & 150 & 1 & 160.19 & 38.71 & 37.39 & 1167.81 & 7.60 & 10.85 & 1.19 \\
\hline 4 & Flour & AIDA & 120 & 1 & 101.75 & 29.44 & $<\mathrm{LOQ}$ & 1075.63 & 6.66 & 10.85 & 1.20 \\
\hline 5 & Kibble & AIDA & 120 & 1 & 79.28 & 30.86 & $<\mathrm{LOD}$ & 655.00 & 4.53 & 6.29 & 1.17 \\
\hline 6 & Kibble & AIDA & 150 & 1 & 147.12 & 37.85 & 36.65 & 1017.81 & 7.66 & 9.82 & 1.21 \\
\hline 7 & Flour & AIDA & 150 & 3 & 154.22 & 36.30 & 35.32 & 1205.69 & 7.68 & 10.60 & 1.23 \\
\hline 8 & Flour & AIDA & - & 3 & 176.32 & 17.47 & $<\mathrm{LOD}$ & 2277.19 & 13.80 & 23.48 & 1.21 \\
\hline 9 & Flour & AIDA & 120 & 3 & 108.54 & 27.16 & $<\mathrm{LOD}$ & 1014.90 & 7.14 & 10.24 & 1.25 \\
\hline 10 & Kibble & AIDA & 150 & 3 & 155.40 & 36.09 & 35.14 & 1028.75 & 8.02 & 9.77 & 1.26 \\
\hline 11 & Kibble & AIDA & 120 & 3 & 87.23 & 26.97 & $<\mathrm{LOD}$ & 823.75 & 6.54 & 8.51 & 1.23 \\
\hline 12 & Flour & AIDA & - & 1 & 94.90 & 18.24 & $<\mathrm{LOD}$ & 1506.88 & 9.95 & 15.41 & 1.18 \\
\hline 13 & Kibble & Galhosa & - & 1 & $<\mathrm{LOQ}$ & 35.38 & $<\mathrm{LOD}$ & 210.83 & 1.00 & 1.57 & 0.43 \\
\hline 14 & Flour & Galhosa & 120 & 3 & 39.35 & 30.49 & $<\mathrm{LOQ}$ & 697.73 & 2.86 & 5.76 & 1.10 \\
\hline 15 & Kibble & Galhosa & 120 & 1 & 33.00 & 34.73 & $<\mathrm{LOD}$ & 501.09 & 2.64 & 5.44 & 1.10 \\
\hline 16 & Flour & Galhosa & 150 & 3 & 47.10 & 23.37 & 39.17 & 653.49 & 3.74 & 7.04 & 1.14 \\
\hline 17 & Kibble & Galhosa & - & 3 & $<\mathrm{LOQ}$ & 30.65 & $<\mathrm{LOD}$ & 238.17 & 1.32 & 2.35 & 0.58 \\
\hline 18 & Flour & Galhosa & 120 & 1 & 34.91 & 32.46 & $<\mathrm{LOQ}$ & 682.34 & 3.02 & 5.24 & 1.09 \\
\hline 19 & Flour & Galhosa & - & 3 & 53.20 & 18.66 & $<\mathrm{LOD}$ & 618.27 & 2.59 & 5.74 & 1.03 \\
\hline 20 & Flour & Galhosa & - & 1 & 27.60 & 34.34 & $<\mathrm{LOD}$ & 322.81 & 1.91 & 6.07 & 0.86 \\
\hline 21 & Flour & Galhosa & 150 & 1 & 54.28 & 36.79 & 40.89 & 766.72 & 4.30 & 9.47 & 1.10 \\
\hline 22 & Kibble & Galhosa & 120 & 3 & 32.01 & 29.81 & $<\mathrm{LOD}$ & 471.28 & 2.58 & 4.96 & 1.10 \\
\hline 23 & Kibble & Galhosa & 150 & 1 & 43.71 & 35.82 & 33.91 & 705.78 & 3.62 & 7.02 & 1.11 \\
\hline 24 & Kibble & Galhosa & 150 & 3 & 55.28 & 24.68 & 36.46 & 659.83 & 3.42 & 5.74 & 1.13 \\
\hline 25 & Kibble & Mulata & 120 & 3 & 31.62 & 33.02 & $<\mathrm{LOQ}$ & 508.89 & 2.83 & 4.37 & 1.02 \\
\hline 26 & Flour & Mulata & - & 3 & 40.94 & 31.16 & $<\mathrm{LOD}$ & 461.31 & 2.56 & 4.98 & 0.86 \\
\hline 27 & Flour & Mulata & 120 & 1 & 30.31 & 32.98 & $<\mathrm{LOQ}$ & 803.44 & 3.79 & 9.41 & 1.08 \\
\hline 28 & Flour & Mulata & 150 & 3 & 64.33 & 34.89 & 41.49 & 884.06 & 5.21 & 9.01 & 1.06 \\
\hline 29 & Kibble & Mulata & 150 & 1 & 59.91 & 38.25 & 50.09 & 794.38 & 4.86 & 9.09 & 1.11 \\
\hline 30 & Flour & Mulata & 150 & 1 & 61.26 & 36.95 & 41.85 & 942.81 & 6.06 & 11.54 & 1.08 \\
\hline 31 & Kibble & Mulata & - & 1 & $<$ LOQ & 33.63 & $<\mathrm{LOD}$ & 213.56 & 0.86 & 3.46 & 0.52 \\
\hline 32 & Kibble & Mulata & 150 & 3 & 63.43 & 35.85 & 41.45 & 673.33 & 5.30 & 8.58 & 1.06 \\
\hline 33 & Kibble & Mulata & 120 & 1 & 22.89 & 34.12 & $<\mathrm{LOQ}$ & 549.53 & 2.52 & 4.05 & 1.03 \\
\hline 34 & Kibble & Mulata & - & 3 & $<\mathrm{LOQ}$ & 32.77 & $<\mathrm{LOD}$ & 202.68 & 1.04 & 2.56 & 0.53 \\
\hline 35 & Flour & Mulata & 120 & 3 & 32.78 & 32.58 & $<\mathrm{LOQ}$ & 723.80 & 3.82 & 7.85 & 1.05 \\
\hline 36 & Flour & Mulata & - & 1 & 30.82 & 36.06 & $<\mathrm{LOD}$ & 361.38 & 1.65 & 6.21 & 0.78 \\
\hline Control & Flour & Mix & $\begin{array}{l}\text { Unknown } \\
\text { roasting }\end{array}$ & 1 & 100.95 & 40.87 & 120.68 & 876.58 & 6.09 & 7.70 & 1.10 \\
\hline Control & Flour & Mix & $\begin{array}{l}\text { Unknown } \\
\text { roasting }\end{array}$ & 3 & 104.43 & 40.32 & 121.39 & 923.75 & 7.04 & 7.27 & 1.07 \\
\hline Gallic acid & Flour & AIDA & - & 3 & 169.47 & & & & & & \\
\hline Furfural & Kibble & Galhosa & 150 & 1 & & 39.61 & & & & & \\
\hline $\begin{array}{l}\text { 5-(hydroxymethyl) } \\
\text { furfural }\end{array}$ & Kibble & AIDA & 150 & 1 & & & 41.93 & & & & \\
\hline TPC & Flour & AIDA & - & 3 & & & & 2212.2 & & & \\
\hline TEAC & Flour & AIDA & - & 3 & & & & & 13.55 & & \\
\hline FRAP & Flour & AIDA & - & 3 & & & & & & 22.48 & \\
\hline Browning Index & Flour & AIDA & 120 & 3 & & & & & & & 1.28 \\
\hline
\end{tabular}




\begin{tabular}{|c|c|c|c|c|c|c|}
\hline \multirow[b]{2}{*}{ Compound } & \multirow{2}{*}{$\begin{array}{l}\mathrm{RT} \\
\min \end{array}$} & \multirow{2}{*}{$\begin{array}{l}\text { Concentration range } \\
\qquad \mathrm{mg} \mathrm{L}^{-1}\end{array}$} & \multirow[b]{2}{*}{ Regression equation $y=a x+b$} & \multirow[b]{2}{*}{$r^{2}$} & LOD & LOQ \\
\hline & & & & & \multicolumn{2}{|c|}{$\mathrm{mg} \mathrm{L}^{-1}$} \\
\hline Gallic acid & 8.53 & $10-125$ & $y=47.485 x+67.097$ & 0.9978 & 6.77 & 22.55 \\
\hline 5-(Hydroxymethyl)furfural & 10.67 & $5-60$ & $y=132.22 x-8.9848$ & 0.9982 & 2.86 & 9.53 \\
\hline Furfural & 12.80 & $5.0-35.0$ & $y=142.44 x-13.642$ & 0.9992 & 1.21 & 4.04 \\
\hline
\end{tabular}

internal standard (IS) at a concentration of $60 \mathrm{mg} \mathrm{L}^{-1}$ to eliminate any relative matrix effect liability. Quantification was determined using external calibration preparing calibration curves of standard solutions, coefficient of determinations $\left(r^{2}\right)$ and limits of detection (LOD) and of quantification (LOQ), as indicate in Table 2.

Both limits were calculated according to the following mathematical Eqns (1) and (2):

$$
\begin{aligned}
L O D & =\frac{3 S_{y / x}}{m} \\
L O Q & =\frac{10 S_{y / x}}{m}
\end{aligned}
$$

where $\mathrm{S}_{\mathrm{y} / \mathrm{x}}=$ the estimation of the standard deviation of the regression line, and $\mathrm{m}=$ slope of the calibration curve.

Stock standard solutions were prepared in Milli-Q water with $45 \%(\mathrm{v} / \mathrm{v})$ of absolute ethanol. All determinations were performed in triplicate.

\section{Total phenolic content (TPC) by Folin-Ciocalteu method}

Total phenolic content (TPC) of each maceration experiment was measured by using a modified Folin-Ciocalteu (FC) colorimetric method $^{21}$ using $\mathrm{FC}$ reagent and employing a one-centimetre quartz cuvette. Briefly, $250 \mu \mathrm{L}$ FC reagent was mixed with $50 \mu \mathrm{L}$ of each carob liquor (with appropriate dilution, if necessary), 45\% ethanol/water (as blank solution) or different concentrations of GA standard solution (50-300 $\mathrm{mg} \mathrm{L}^{-1}$ ). Then, $750 \mu \mathrm{L} 7 \% \mathrm{Na}_{2} \mathrm{CO}_{3}$ were added and the mixture was completed to $5 \mathrm{~mL}$ with pure water. The reaction was incubated at room temperature in the dark for $2 \mathrm{~h}$. The absorbance was measured at $760 \mathrm{~nm}$. The quantification of the samples was carried out using a calibration curve with known concentrations of GA and the results were expressed as GA equivalents (GAE) per liter of liquor (mg GAE/L).

\section{Antioxidant capacity by ferric reducing antioxidant power (FRAP)}

The FRAP assay was performed as described by Yen and Chen ${ }^{22}$ with slight modifications. Briefly, $100 \mu \mathrm{L}$ of ethanol: water $(45 \%$ $\mathrm{v} / \mathrm{v}$ ), ascorbic acid standard solutions prepared in phosphate buffer $\left(0.0625-0.125-0.25-0.5 \mathrm{mmol} \mathrm{L}^{-1}\right)$ or carob liquor were mixed with sodium phosphate buffer $\left(250 \mu \mathrm{L}, 200 \mathrm{mmol} \mathrm{L}^{-1}\right.$, $\mathrm{pH} 6.6)$ and $1 \%$ of potassium ferricyanide water solution $(250 \mu \mathrm{L}$, $\left.\mathrm{K}_{3}\left[\mathrm{Fe}(\mathrm{CN})_{6}\right]\right)$. The mixture was incubated at $50{ }^{\circ} \mathrm{C}$ for $20 \mathrm{~min}$ in a water bath. Aliquots of trichloroacetic acid $(250 \mu \mathrm{L}, 10 \%$ aqueous solution, TCA) were added to the mixture which was centrifuged at $3000 \mathrm{rpm}$ for $10 \mathrm{~min}$. Finally, the supernatant $(400 \mu \mathrm{L})$ was mixed with water $(400 \mu \mathrm{L})$ and $\mathrm{FeCl}_{3}(80 \mu \mathrm{L}, 0.1 \%)$ in a $1 \mathrm{~cm}$ quartz cuvette. Reducing activity was measured by determining the absorbance at $700 \mathrm{~nm}$ using a T70 + UV-Visible Spectrophotometer (PG instruments Ltd, UK) and the results were expressed as ascorbic acid equivalents per liter of liquor (mmol AAE/L). All determinations were performed in triplicate.

\section{Antioxidant capacity by trolox method (TEAC)}

Based on the protocol described by $\mathrm{Re}$ et al. ${ }^{23}$ the sodium phosphate buffer $\left(7 \mathrm{mmol} \mathrm{L}^{-1}, \mathrm{pH}\right)$ and trolox solutions at different concentrations $\left(0.1-0.5 \mathrm{mmol} \mathrm{L}^{-1}\right)$, were prepared. The ABTS $^{+} \quad$ [2,2'-azino-bis(3-ethylbenzothiazoline-6-sulfonic acid)] (7 $\mathrm{mmol} \mathrm{L}^{-1}$ ) was also formed in a solution of potassium persulfate $\left(2.45 \mathrm{mmol} \mathrm{L}^{-1}\right)$, which was kept in the dark for 12 to $16 \mathrm{~h}$ at room temperature. To obtain the working solution, the ABTS ${ }^{+}$was diluted to an absorbance of approximately 0.7 at $734 \mathrm{~nm}$.

Samples were read into 96-well microplates. In each well were mixed $10 \mu \mathrm{L}$ of sample, phosphate buffer (blank) or trolox (standard antioxidant) with $190 \mu \mathrm{L}$ of $\mathrm{ABTS}^{+}$working solution. The absorbance was read at $734 \mathrm{~nm}$ using a Tecan Infinite M200 microplate reader. The results are expressed as micromole of trolox equivalents (TE) per liter of liquor ( $\mu \mathrm{mol} T E / L)$.

\section{Browning index (BI)}

The measurement of the absorbance at $420 \mathrm{~nm}$ in a T70 + UV-Visible Spectrophotometer (PG instruments Ltd, UK) is a way to monitor the reaction process of the non-enzymatic browning reactions, the Maillard reaction and the caramelization, ${ }^{16}$ i.e., to know the status of the formation of the browning products. ${ }^{24}$ This is of prime importance as both reactions affect the quality of processed products in relation to the sensory attributes (color, flavour and taste). ${ }^{25}$

\section{Experimental design and statistical analysis}

An experimental design resulting in a matrix of 36 experiments (Table 1) was planned to evaluate the effect of carob characteristics (roasting degree, particle size and variety) and maceration periods ( 1 or 3 weeks) on the chemical composition and antioxidant capacity of carob liquors. Four independent variables were studied at two or three levels: roasting degree, particle size and variety of $C$. siliqua fruits, as categorical parameters, and the maceration period, as numerical parameter. The dependent variables studied were the phenolic content (GA and TPC) and furanic composition (furfural and HMF), the antioxidant capacity determined by FRAP and TEAC assays and the browning index of carob liquors. Results were assessed with descriptive statistics such as $F$-value, coefficient of determination $\left(r^{2}\right), P$-value, standard error, absolute error, Durbin-Watson statistic and model equations to reflect the statistical significance of the model. The good adjustment of the model to the experimental data was demonstrated by the high 


\begin{tabular}{|c|c|c|c|c|c|c|c|}
\hline Response & $F$-value & $\mathbf{r}^{2}$ & $P$-value & $\begin{array}{l}\text { Standard } \\
\text { Error }\end{array}$ & $\begin{array}{l}\text { Absolute } \\
\text { Error }\end{array}$ & $\begin{array}{l}\text { Durbin-Watson } \\
\text { statistic }\end{array}$ & Model equation \\
\hline $\begin{array}{l}\text { Total phenolic } \\
\text { content }\end{array}$ & 14.6481 & 0.9913 & 0.009 & 111.01 & 32.3362 & 1.98444 & $\begin{array}{l}\text { 734.43-163.7 PS }-331.6 \mathrm{~V}+115.1 \mathrm{RT}+145 \\
\mathrm{PS} \cdot \mathrm{V}+141.64 \mathrm{PS} \cdot \mathrm{RT}+249.7 \mathrm{~V} \cdot \mathrm{RT}-241.05 \mathrm{PS} \cdot \mathrm{V} \cdot \mathrm{RT}\end{array}$ \\
\hline Gallic acid & 19.3856 & 0.9934 & 0.0052 & 11.0724 & 3.14926 & 1.82919 & $\begin{array}{l}\text { 62.54-10.4 PS - 48.78V + 16.57 RT + 10.94 PS.V } \\
\quad+14.28 \text { PS.RT }\end{array}$ \\
\hline Furfural & 14.5985 & 0.9912 & 0.009 & 1.73989 & 0.491543 & 1.59433 & $\begin{array}{l}31+2.96 \mathrm{~V}+3.85 \mathrm{RT}-2.11 \mathrm{MT}-5.92 \mathrm{~V} \cdot \mathrm{RT} \\
-1.08 \mathrm{~V} \cdot \mathrm{MT}\end{array}$ \\
\hline HMF & 109.144 & 0.9988 & 0.0002 & 1.8401 & 0.514938 & 2.31885 & $14.19+1.11 \mathrm{~V}+13.69 \mathrm{RT}$ \\
\hline TEAC & 35.387 & 0.9964 & 0.0016 & 0.495898 & 0.141804 & 2.26148 & $\begin{array}{l}4.51-0.73 \mathrm{PS}-2.89 \mathrm{~V}-0.43 \mathrm{RT}+0.68 \mathrm{MT}+0.26 \mathrm{MT} \\
+0.67 \mathrm{PS} \cdot \mathrm{V}+0.85 \mathrm{PS} \cdot \mathrm{RT}+1.54 \mathrm{~V} \cdot \mathrm{RT}+1.36 \mathrm{PS} \cdot \mathrm{V} \cdot \mathrm{RT}\end{array}$ \\
\hline FRAP & 6.419 & 0.9802 & 0.0411 & 1.66471 & 0.445656 & 1.94706 & $7.66-1.77 \mathrm{PS}-3.03 \mathrm{~V}+1.5 \mathrm{PS} \cdot \mathrm{RT}+1.36 \mathrm{~V} \cdot \mathrm{RT}$ \\
\hline Browning Index & 102.632 & 0.9987 & 0.0002 & 0.0223622 & 0.00583951 & 1.85749 & $\begin{array}{l}1.03-0.05 \mathrm{PS}-0.15 \mathrm{~V}+0.2 \mathrm{RT}+0.02 \mathrm{MT}-0.02 \mathrm{PS} \cdot \mathrm{V} \\
\quad+0.01 \mathrm{PS} \cdot \mathrm{RT}+0.12 \mathrm{~V} \cdot \mathrm{RT}-0.01 \mathrm{~V} \cdot \mathrm{MT}-0.027 \mathrm{RT} \cdot \mathrm{MT} \\
\quad+0.04 \mathrm{PS} \cdot \mathrm{V} \cdot \mathrm{RT}\end{array}$ \\
\hline
\end{tabular}

coefficient of determination $\left(r^{2}\right)$ values, close to 1 (Table 3). On the basis of the high Fisher' $S$ ' $F$ ' $\left(F_{\text {tab (0.05) }}>5.729\right)$ and the low probability ' $P$ ' $(P<0.05)$ values, the highly significant regression of the model is justified. In addition, the terms of the equations were selected based on their significance of the $P<0.05$ values.

Pearson's correlations ( $r$ ) (Table 4) were performed to assess the relationships among the different dependent variables studied, and correlations with $P<0.05$ were considered statistically significant. The data were subjected to principal component analysis (PCA) to examine the differences amongst the carob liquors according to the roasting degree and the carob variety used in liquor preparation using XLSTAT Software (Addinsoft, New York, NY, USA). The experimental design results and the correlation tests were analysed by the software Statgraphics Centurion XVI (StatPoint Technologies, Inc., Warrenton, VA, USA).

\section{RESULTS AND DISCUSSION \\ Gallic acid (GA) and total phenolic content (TPC) in carob liquors}

The phenolic GA, and the TPC were quantified in carob liquors using a photodiode array detector (HPLC-PDA) and the Folin-Ciocalteu spectrophotometric method, respectively. The results of both parameters in the different carob liquors can be observed in Table 1. These dependent variables presented a strong significant correlation (Table 4). This is expected since GA is the most abundant phenolic found in carob liquors, as shown in chromatograms from Fig. 1. GA and TPC are strongly influenced by the carob variety used (Fig. 2(a.1), (a.2), (b.1) and (b.2)). The trend observed concerning AIDA liquors was very different from those of Mulata and Galhosa (Fig. 1(a.1), (a.2), (b.1), (b.2), (c.1) and (c.2)). Custódio et al. ${ }^{13}$ also found differences in TPC for the same two groups of differentiated varietal methanolic extracts, AIDA and Mulata/Galhosa. According to the impact of independent variables and their interactions (Fig. 2(a.1) and (b.1)), particle size and roasting degree are variables with significant influence on phenolic content, while the maceration period was not statistically important. The higher GA content was recorded in liquors elaborated from unroasted AIDA carob flour (Fig. 1(c)), in particular runs 8 (3 weeks of maceration) and 12 (1 week) (Table 1). However, the TPC decreased from unroasted to roasted AIDA liquors. This tendency can be explained by the decrease of GA content observed in the roasted samples. Liquors produced from unroasted AIDA carob flour after 3 weeks of maceration presented the higher GA concentration $\left(3.5 \mathrm{~g} \mathrm{Kg}^{-1}\right.$ ) (run 8 , Table 1). However, when the carob sample was subjected to $120^{\circ} \mathrm{C}$, the GA concentration drops to $2.2 \mathrm{~g} \mathrm{Kg}^{-1}$ (run 9, Table 1). This trend seems to be justified by the fact that when the temperature is increased to $120^{\circ} \mathrm{C}$, part of the free GA present in the unroasted sample was degraded and although more free GA was probably releasing from the degradation of high molecular weight compounds, the net balance was the decrease of GA. ${ }^{15}$ When carob flour roasted at $150^{\circ} \mathrm{C}$ was used (run 7, Table 1), the resulting liquor presented an increase in the GA content of a $29.0 \%$, in relation to the other roasting temperature tested $\left(120^{\circ} \mathrm{C}\right)$, but still lower $\left(3.1 \mathrm{~g} \mathrm{~kg}^{-1}\right)$ than the value of the unroasted sample. The release of gallic acid from more complex structures seems to be predominant in this sample, despite the degradation of free GA.

Despite the results found in AIDA liquors, according to the chart of main effects the general tendency is the higher the roasting degree of carob pod, the better the extraction of GA (Fig. 2(b.2)) and the greater the values of TPC (Fig. 2(a.2)). This can be explained by the release of GA through the ruptured of high-molecular complexes from carob matrix during the roasting step. ${ }^{15}$ Accordingly, the highest GA concentration in Mulata and Galhosa liquors was found in roasted flour liquors with values of $1.3 \mathrm{~g} \mathrm{~kg}^{-1}$ (run 28, Table 1) and $1.1 \mathrm{~g} \mathrm{~kg}^{-1}$ (run 21, Table 1), respectively. These values were lower than those of the plurivarietal roasted commercial liquor $\left(2.09 \mathrm{~g} \mathrm{~kg}^{-1}\right)$ used as control (Table 1) and the methanolic extracts from Turkish carob $\left(12.5 \mathrm{~g} \mathrm{~kg}^{-1}\right){ }^{7}$ but higher to those found in different roasted carob acetone/water $(50 \% \mathrm{v} / \mathrm{v})$ extracts $\left(0.3-0.7 \mathrm{~g} \mathrm{Kg}^{-1}\right){ }^{9}$ In addition to the influence of the variety, the results may be affected by the type of solvent used during the extraction procedure, and some works concluded that the solubility of GA was higher with the following solvents methanol>ethanol> water>acetone. ${ }^{26,27}$

According to Şahin et al. ${ }^{16}$, the increase in the TPC of the roasted carob extracts could also be explained by the formation of MRPs with phenolic type structure during the roasting process because these type of compounds are also detected by Folin-Ciocalteu reagent. In this regard, the TPC content of roasted carob liquors increased more than two-fold compared with unroasted liquors (with 1 week of maceration) using Galhosa 
Table 4. Pearson correlation matrix among phenolic and furanic composition, antioxidant activity (TEAC and FRAP methods), and browning index

\begin{tabular}{|c|c|c|c|c|c|c|c|}
\hline & TPC & Gallic acid & Furfural & HMF & TEAC & FRAP & $\mathrm{BI}$ \\
\hline TPC & 1.000 & $0.8375^{*}$ & -0.256 & 0.250 & $0.955^{*}$ & $0.962^{*}$ & $0.684^{*}$ \\
\hline Gallic acid & & 1.000 & -0.0305 & 0.372 & $0.889^{*}$ & $0.769^{*}$ & $0.651^{*}$ \\
\hline Furfural & & & 1.000 & 0.435 & -0.267 & -0.248 & -0.147 \\
\hline HMF & & & & 1.000 & 0.277 & 0.255 & 0.381 \\
\hline TEAC & & & & & 1.000 & $0.934^{*}$ & $0.691^{*}$ \\
\hline FRAP & & & & & & 1.000 & $0.620^{*}$ \\
\hline $\mathrm{BI}$ & & & & & & & 1.000 \\
\hline
\end{tabular}
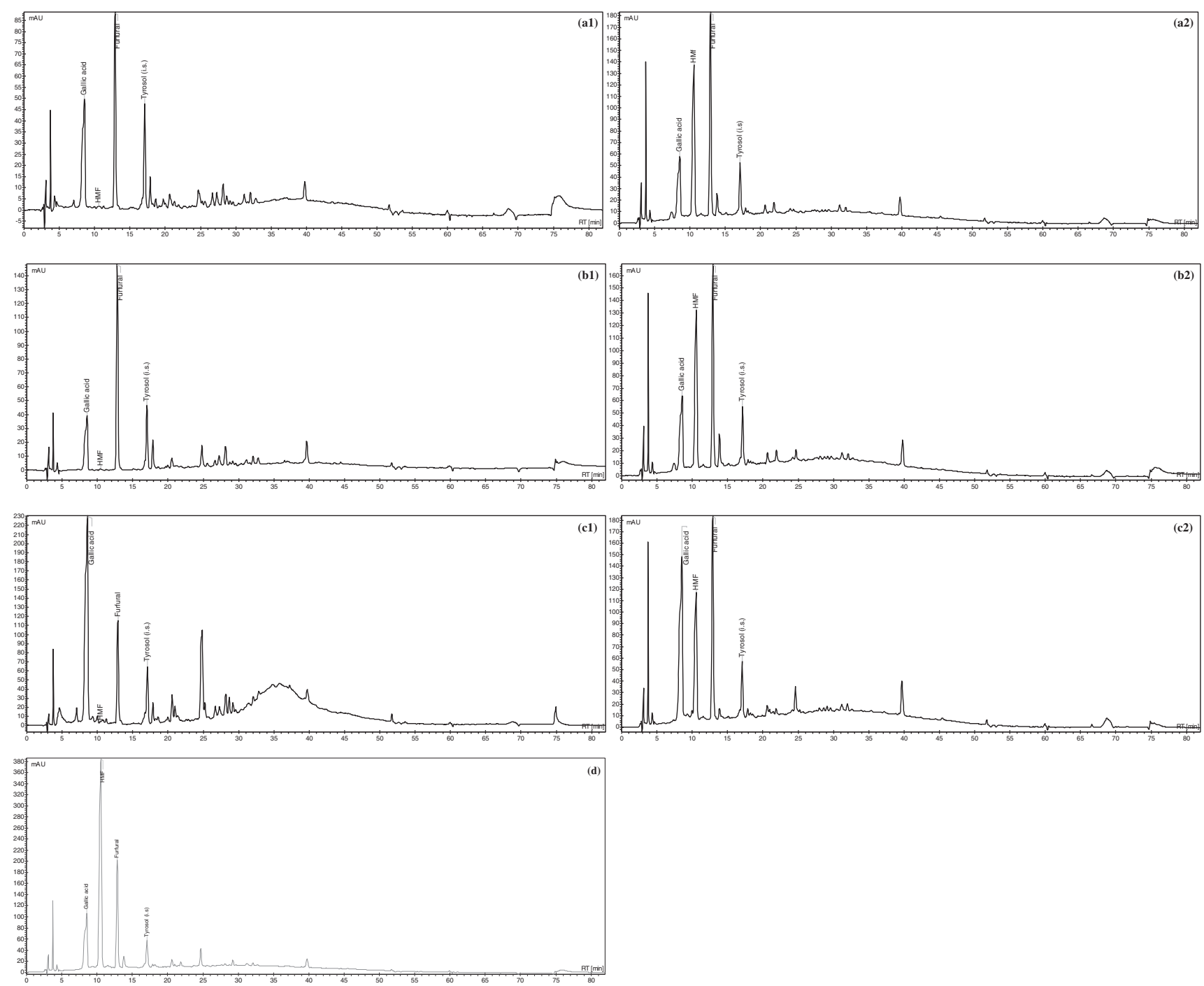

Figure 1. HPLC chromatograms of unroasted (1) and roasted $\left(150^{\circ} \mathrm{C}\right)(2)$ Galhosa (a), Mulata (b) and AIDA (c) carob liquors and a roasted commercial plurivarietal carob liquor (d) recorded at $280 \mathrm{~nm}$. Peak identification: gallic acid (8.53 min), 5-(hydroxymethyl)furfural (HMF; $10.67 \mathrm{~min}$ ), furfural (12.80 min) and tyrosol (internal standard, i.s.; $16.96 \mathrm{~min}$ ).

(from 6.40 to $15.3 \mathrm{~g} \mathrm{~kg}^{-1}$ ) (Table 1; runs 20 and 21, respectively) and Mulata (from 7.2 to $18.9 \mathrm{~g} \mathrm{~kg}^{-1}$ ) (runs 36 and 30 , respectively) varieties. Similar increases were observed from unroasted to roasted carob aqueous extracts by Şahin et al. ${ }^{16}$ (from 5.70 to $9.86 \mathrm{~g} \mathrm{~kg}^{-1}$ ), Čepo et al. ${ }^{15}$ (from 7.60 to $13.10 \mathrm{~g} \mathrm{~kg}^{-1}$ ) and Srour et al. ${ }^{2}$ (from 11 to $23 \mathrm{~g} \mathrm{~kg}^{-1}$ ).
Quantification of furfural and 5-(hydroxymethyl)furfural. Estimation of their daily intake based on carob liquors consumption

The Maillard reaction and sugar pyrolysis intermediates formed during thermal processing of foods, furfural $(F)$ and especially 5-(hydroxymethyl)furfural (HMF), presented a remarkable increase 

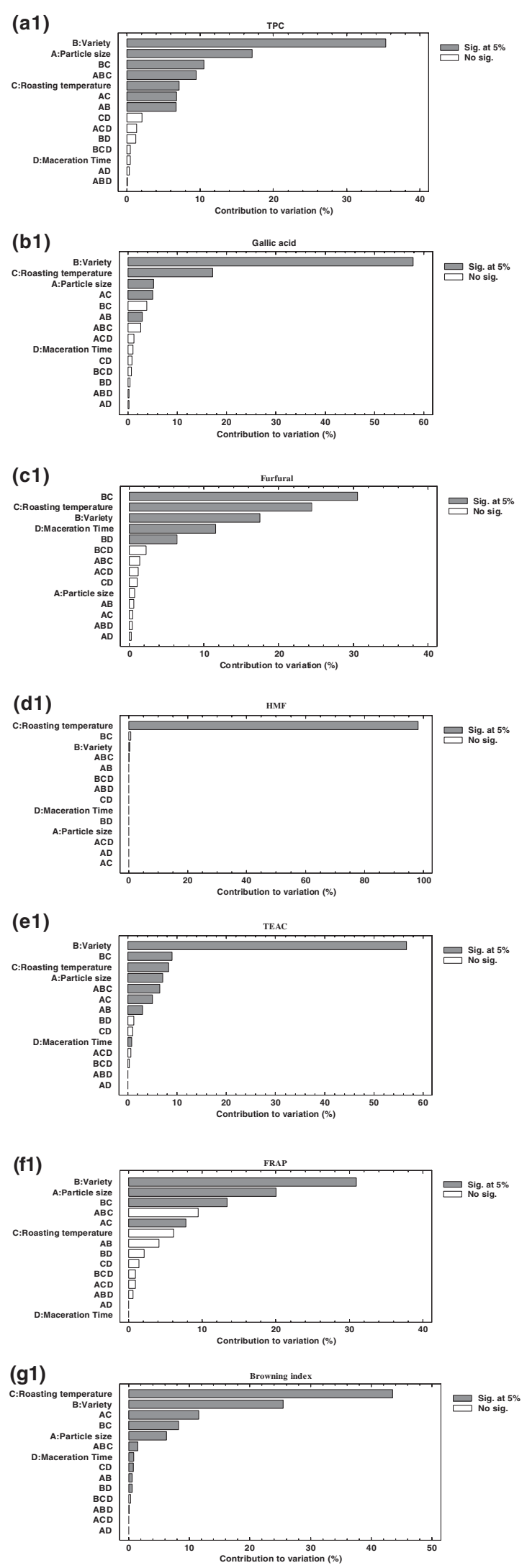

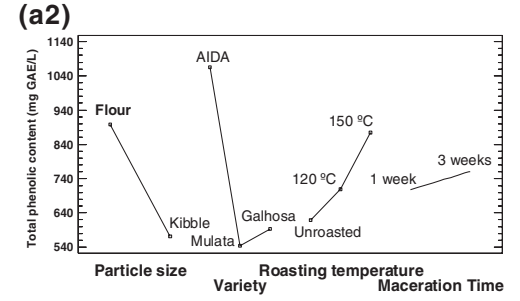

(b2)

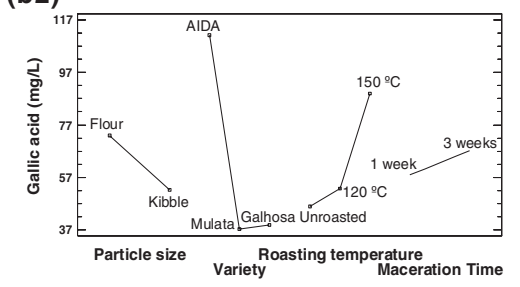

(c2)
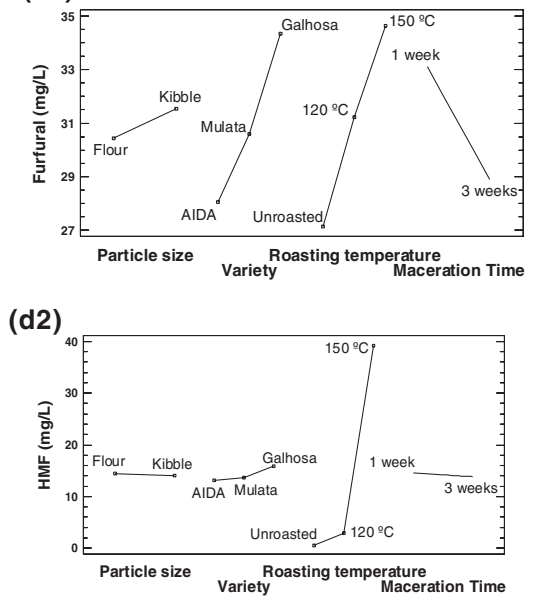

(e2)

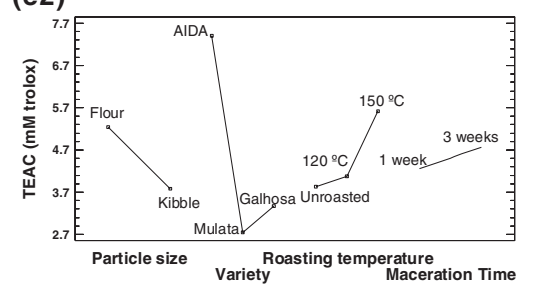

(†2)

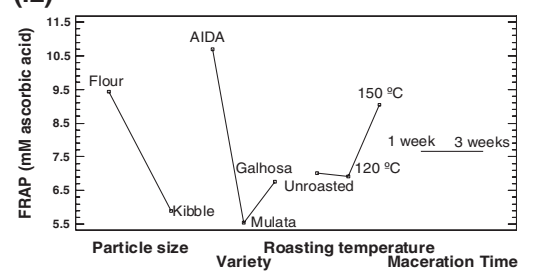

(g2)

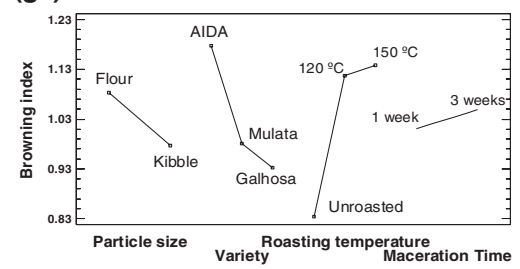

Figure 2. Pareto charts (1) [dark grey bars indicate the statistical significance of the effects ( $95 \%$ confidence level)] and main effects (2) of different levels of studied independent variables (particle size, variety, roasting temperature and maceration time) on total phenolic content (TPC) (a), gallic acid (b), furfural (c), 5-(hydroxymethyl)furfural (HMF) (d), antioxidant capacity (TEAC (e) and FRAP (f) assays), and browning index (g) of carob liquors. 
from unroasted to roasted carob liquors with the maximum values at $150^{\circ} \mathrm{C}$ (Table 1$) .^{28}$ Therefore, as expected, the main factor affecting the content of both compounds is the roasting temperature as shown in Pareto and main effects charts (Fig. 2(c.1) and (c.2) for F and (d.1) and (d.2) for HMF). The other variables had no significant influences in the variability of HMF concentration. It is worth noting the great differences in the concentrations of HMF from liquors made with carob processed in the laboratory against carob from commercial origin (see Table 1 and Fig. 1). This commercial sample presented quantities of HMF up to three times higher than those produced with carob roasted at $150^{\circ} \mathrm{C}$, and therefore roasting temperatures higher than those of this work must have used.

In the case of $F$, the interaction roasting temperature-variety followed by the carob variety, the maceration period and the interaction variety-maceration time, were the parameters with greater influence on the generation or degradation of this compound (Fig. 2(c.1)). In general, the increase (from one to 3 weeks) of the maceration period favours the reduction of the furanic content [particularly in the case of F extraction, see Fig. 2(c.2)], probably due to chemical reactions taking place in liquor matrix. These chemical reactions could include the polymerization or the conversion of the furanic compounds to the corresponding alcohols and acids by the action of the residual air present in the bottle, also further degradations could be carried out from furfural to formic acid and 5-HMF to formic and levulinic acids. ${ }^{29-32}$ The small differences of $F$ found in varietal liquors could possibly be explained by different concentrations of pentoses in the carob fruit that were degraded to $F$. The concentration of $F$ found in samples of unroasted carob liquors comes mainly from the spirit used in the production process. This compound is originated during the fired pot-still distillation process at high temperatures. ${ }^{33,34}$ However, the high concentrations found in the unroasted Mulata (runs 26, 31, 34 and 36 of Table 1) and Galhosa liquors (runs 13, 17 and 20 of Table 1) may be explained by the different degrees of heat sensitivity of the raw material ${ }^{35}$ due to the different composition (sugars, amino acids, etc) of Galhosa and Mulata varieties in relation to AIDA.

$\mathrm{F}$ and HMF are compounds considered toxic to many types of organism including mammalian cells $\mathrm{s}^{36}$ and thus it is important to know their daily exposure to understand how they can affect the human health. The $\mathrm{F}$ and HMF estimated daily intake

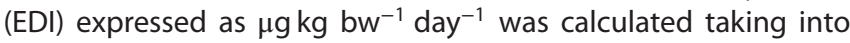
account an average body weight of $70 \mathrm{~kg}$ and a daily consumption of carob liquor per person of approximately $50 \mathrm{~mL}$ (equivalent to a standard liquor glass). The maximum EDI of $F$ found in samples was between $26.28 \mu \mathrm{gg} \mathrm{bw}^{-1}$ day $^{-1}$ and $29.19 \mu \mathrm{g} \mathrm{kg}$ $\mathrm{bw}^{-1}$ day $^{-1}$. These EDIs were about five to ten times below the theoretical added maximum daily intake (TAMDI, $136 \mu \mathrm{g} \mathrm{kg} \mathrm{bw}^{-1}$ ) and the intake from natural sources $\left(300 \mu \mathrm{g} \mathrm{kg} \mathrm{bw}^{-1}\right)$ estimated for this compound. ${ }^{37}$ The TAMDI assumes that the consumer will day in day out take a fixed standard amount of flavoured food and beverages which will always contain the specific flavouring at its specified upper use level. On the other hand, the maximum EDI values $\left(26.71-86.71 \mu \mathrm{gg} \mathrm{bw}^{-1}\right.$ day $\left.^{-1}\right)$ of HMF found in carob liquors were well below the benchmark dose lower confidence limit (BMDL) $\left(79 \mathrm{mg} \mathrm{kg} \mathrm{bw}^{-1}\right.$ day $^{-1}$ ) (dose that corresponds to a specific change in an adverse response compared to the response in unexposed subjects), ${ }^{38}$ the range of average daily intake of $30-150 \mathrm{mg}$ person ${ }^{-1}$ established by Janzowski et al., ${ }^{39}$ and the threshold of concern $\left(540 \mu\right.$ g person $^{-1}$ day $\left.^{-1}\right)$ and the modified theoretical added maximum daily intake (mTAMDI,
$1600 \mu \mathrm{g}_{\text {person }}{ }^{-1}$ day $^{-1}$ ) established by the European Food Safety Authority. ${ }^{37}$

\section{Antioxidant capacity (AC) and browning index (BI) of varietal carob liquors}

The AC results determined by FRAP and TEAC methods are directly related to the TPC and GA content, as can be concluded by the similar trend observed in Fig. 2(a.1-2, b.1-2, e.1-2 and f.1-2) and the high correlations found among them (Table 4). However, these chemical methods present a questioned ability to predict in vivo activity because some assays are performed at non physiological $\mathrm{pH}$ and temperature, and they do not include the bioavailability, uptake and metabolism of the antioxidant compounds, among other aspects. ${ }^{40}$ On the other hand, nowadays the use of in vitro biological assays such as the cell-culture based assays has increased to study the antioxidant capacity of foods since these methods are relatively fast, and address some issues of uptake, distribution and metabolism. ${ }^{40}$ In the present work, the antioxidant capacity was evaluated using chemical methods to allow comparison with the current available literature of this type of samples.

The variety, the particle size and the interactions variety-roasting degree and particle size-roasting degree are the main factors affecting the AC values (Fig. 2(e.1) and (f.1)). The sample prepared with the unroasted AIDA flour presented the highest TEAC value, $276 \mathrm{mmol} \mathrm{TE} \mathrm{kg}^{-1}$ (run 8, Table 1). This concentration was similar to those of extracts prepared with roasted carobs $(208-252 \mathrm{mmol}$ $\mathrm{TE} \mathrm{kg}{ }^{-1}$ ) and unroasted carobs from Jnoubi (211 $\mathrm{mmol} \mathrm{TE} \mathrm{kg}^{-1}$ ) and Makdissi Jnoub (211 mmol TE kg ${ }^{-1}$ ) Lebanese varieties. ${ }^{2}$ However, lower concentration (153.6 mmol TE kg-1) was found in AIDA liquors prepared with carob flour roasted at $150^{\circ} \mathrm{C}$ (run 7 , Table 1). This value was still higher than those of the other varietal liquors studied, but closer to the commercial roasted carob flour liquor (145.4 mmol TE kg-1), and the unroasted and roasted soluble ( 83.38 and $142.99 \mathrm{mmol} \mathrm{TE} \mathrm{kg}{ }^{-1}$, respectively) and insoluble ( 143.27 and $154.78 \mathrm{mmol} \mathrm{TE} \mathrm{kg}{ }^{-1}$ respectively) carob aqueous fractions obtained after a digestion process by Čepo et $a l .^{15}$ On the other hand, liquors prepared with roasted carob of the varieties Mulata (104.2 $\mathrm{mmol} \mathrm{TE} \mathrm{kg}^{-1}$ ) (run 28, Table 1) and Galhosa (74.8 $\mathrm{mmol} \mathrm{TE} \mathrm{kg}^{-1}$ ) (run 16, Table 1) presented values $51 \%$ and $31 \%$ higher, respectively, than the corresponding unroasted carob liqueurs for the same time of maceration. Similar AC of roasted Mulata liquor was observed in aqueous roasted carob extracts (105.7 mmol TE $\mathrm{kg}^{-1}$ ) by Şahin et al. ${ }^{16}$

In addition to the mentioned factors, the roasting degree and the triple interaction variety-roasted degree-particle size were other factors affecting the TEAC values of carob liquors (Fig.2(e.1)). In general, varietal liquors prepared with the highest roasting degree of carob $\left(150^{\circ} \mathrm{C}\right)$ and the smallest particle size (flour) presented the highest $A C$ (TEAC) results (Fig. 2(e.2)). On the other hand, significant differences in AC by TEAC and browning index (Fig. 2(e.1) and (g.1)) were observed for both periods of maceration studied, with slightly higher values in liquors with the longest maceration time (Fig. 2(e.2) and (g.2)).

No significant correlations were observed between $\mathrm{BI}$ (a measure of melanoidins content, compounds known as final products of Maillard and caramelization reactions) ${ }^{41}$ and the furanic compounds ( $F$ and HMF, intermediaries of that reactions) (Table 4), parameters associated with the roasting process. This is due to the fact that these intermediaries can produce other final products such as aldols and free polymers or they can react with amino acids to produce aldimines or ketimines as a complex network of reactions involving the Maillard reaction. ${ }^{42}$ Therefore, there is no direct 
Biplot (axes PC1 and PC2: $83.79 \%$ )

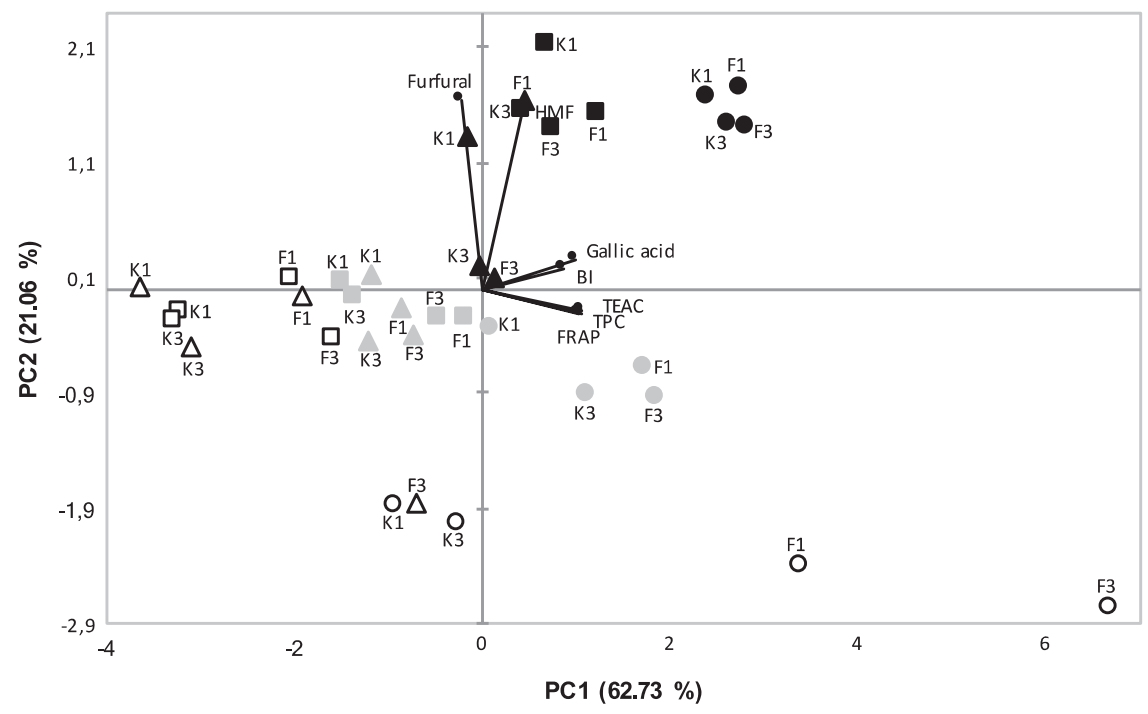

Figure 3. Principal component analysis plot of carob liquors (n. 36) from varieties AIDA (circles), Mulata (squares) and Galhosa (triangles) with different roasting degrees $\left[150^{\circ} \mathrm{C}\right.$ (black), $120^{\circ} \mathrm{C}$ (grey) and unroasted (white)], particle sizes [kibble (K) and flour (F)] and times of maceration (1 or 3 weeks), and selected variables (n. 7).

link between reactants, intermediary products ( $F$ and HMF), and the final products melanoidins. The main factors influencing the browning index are the roasting degree followed by carob variety (Fig. 2(g.1)). The smaller the particle size (flour), the longer the maceration period ( 3 weeks), as well as the higher the roasting degree $\left(150^{\circ} \mathrm{C}\right)$ (Fig. 2(g.2)). The AIDA variety produced the greater values of this index. $\mathrm{BI}$ results in Galhosa and Mulata liquors produced from unroasted kibbles (runs 13, 17, 31 and 34 of Table 1) have nearly doubled those of roasted kibbles at $120^{\circ} \mathrm{C}$ (runs $15,22,25$ and 33 of Table 1). In the case of samples made with carob flour, the increase was between $6 \%$ and $28 \%$ for Galhosa (runs 14, 18-20, Table 1) and Mulata liquors (runs 26, 27, 35 and 36, Table 1), respectively. This increase was lower in AIDA liquors prepared with carob flour (3\%) and carob kibble (35\%). The high values observed in unroasted carob liquors may be caused by the extraction and/or formation of brown-coloured pigments during the carob drying process. In particular, the dehydration of the fruit during the drying process can alter the cell structure and facilitate the contact of the polyphenol oxidases enzymes with their substrates producing the enzymatic browning involving phenolic compounds. ${ }^{43}$ Moreover, a small increase (between $0.9 \%$ and $7 \%$ ) was observed in $\mathrm{BI}$ values with the increase of roasting temperature from 120 to $150^{\circ} \mathrm{C}$ (Table 1). This rise in $\mathrm{BI}$ values was much lower than that observed by Şahin et al. ${ }^{16}$ an increase of $60 \%$ from 135 to $165^{\circ} \mathrm{C}$, mainly observed during the first 5 min of thermal treatment, regardless of the applied temperature. ${ }^{15}$

\section{Principal component analysis}

Figure 3 shows the biplot of the two main principal components $(P C 1 \times P C 2)$ characterized by the GA and TPC, AC using FRAP and TEAC methods, and the furanic content ( $F$ and HMF) and $\mathrm{BI}$ of 36 liquors obtained from different carob varieties with a cumulative explained total variance of $84.9 \%$. The first and second principal component (PC1 and PC2) accounted for $63.4 \%$ and $21.5 \%$ of the variability in the data set, respectively. The first principal component (PC1) was mostly characterized positively by the TEAC $(0.951)$, TPC (0.934), FRAP (0.876), GA (0.814) and BI (0.624). The second principal component $(\mathrm{PC} 2)$ was mostly characterized positively by furfural (0.768) and HMF (0.645). According to these figure, distinct groups were identifiable for all carob liquors primarily according to the roasting degree and variety of carob used in liquor preparation. In general, unroasted or roasted at $120^{\circ} \mathrm{C}$ carob liquors are positioned on left side of PC1 (second and third quadrant). These samples showed the lowest values of $A C$ and phenolic and furanic content. However, AIDA liquors prepared from unroasted and roasted carob flour at $120^{\circ} \mathrm{C}$, together with roasted $\left(150^{\circ} \mathrm{C}\right)$ carob liquors from the three carob varieties were located on the right side of the $\mathrm{PC} 1$, the whole fourth and first quadrants. These samples presented the highest values of phenolic content (GA and TPC) and AC by FRAP and TEAC methods. Unsurprisingly, these variables are clustered together on the right side of the loading plot since they are significantly correlated as evidenced by their Pearson correlation coefficients (Table 4). Interestingly, AIDA liquor prepared from unroasted flour during 3 weeks of maceration (AFU3) is located quite some distance away from all of the other carob liquors, indicating that its composition differs significantly from the other samples. It should also be emphasised that all roasted $\left(150^{\circ} \mathrm{C}\right)$ carob liquors occupied a unique location at the first quadrant of Fig. 3. This location may be explained by the high values of HMF which is located in this region of the PCA biplot.

\section{CONCLUSIONS}

The carob roasting degree and variety have a clear effect on mostly of the dependent variables studied in carob liquors. The trend of the results showed noticeable differences between two groups of samples, one comprising AIDA liquors, and the other including liquors prepared with Mulata and Galhosa varieties. AIDA liquors (mainly those prepared from unroasted flour) and Mulata and Galhosa liquors prepared from roasted at $150^{\circ} \mathrm{C}$ carob flour presented the highest TPC, AC (FRAP and TEAC) and GA content. In general, the results obtained suggest a safe consumption of these beverages according to the furanic content, since even the maximum values of furfural and HMF obtained in roasted carob liquors were within the levels for safe consumption. In Galhosa and Mulata liquors a small increase $(<7 \%)$ of $\mathrm{BI}$ (Maillard products) values 
was observed with the increase of roasting temperature from 120 to $150^{\circ} \mathrm{C}$. The use of the lowest particle size (flour) and the longest maceration period ( 3 weeks) provided liquors with the greatest phenolic content (TPC and GA) and AC values, and the lowest toxic furanic content ( $F$ and HMF). Therefore, these conditions can help to obtain healthier liquors.

\section{ACKNOWLEDGEMENTS}

The authors wish to thank the collaboration of Eng. João Costa and Eng. José Fernando Prazeres, from DRAP Algarve for providing the carob pods, Miguel Nuno Ferreira Dantas for his helpful assistance in sample preparation, and Dr. Ludovina Galego and Dr. Maria Margarida Cortez Vieira from University of Algarve (ISE) for the use of laboratory equipment. We are also very grateful to Ángel R. de Lera and Rosana Álvarez from the Organic Chemistry Department, Faculty of Chemistry and Centro de Investigaciones Biomédicas (CINBIO), University of Vigo, for their valuable contributions.

This work was supported by the Fundação para a Ciência e a Tecnologia (Grant no. SFRH/BPD/103086/2014) and by the project INTERREG - MD.Net: When Brand Meets People. José Manuel Salgado was supported by grant CEB/N2020 - INV/01/2016 from Project "BIOTECNORTE - Underpinning Biotechnology to foster the north of Portugal bioeconomy" (NORTE-01-0145-FEDER-000004).

\section{SUPPORTING INFORMATION}

Supporting information may be found in the online version of this article.

\section{REFERENCES}

1 Food and Agriculture Organization of the United Nations statistics (FAOstat). Production data from 2013 to 2016 on carob for all countries and regions in the world (2018) Available: http://www.fao .org/faostat/en/?\#data/QC [1 April 2018].

2 Srour N, Daroub H, Toufeili I and Olabi A, Developing a carob-based milk beverage using different varieties of carob pods and two roasting treatments and assessing their effect on quality characteristics. J Sci Food Agric 96:3047-3057 (2016). http://doi.org/10.1002/jsfa .7476 .

3 Roseiro LB, Duarte LC, Oliveira DL, Roque R, Bernardo-Gil MG, Martins Al et al., Supercritical, ultrasound and conventional extracts from carob (Ceratonia siliqua L.) biomass: effect on the phenolic profile and antiproliferative activity. Ind Crops Prod 47:132-138 (2013). https://doi.org/10.1016/j.indcrop.2013.02.026.

4 Yousif AK and Alghzawi HM, Processing and characterization of carob powder. Food Chem 69:283-287 (2000). https://doi.org/10.1016/ S0308-8146(99)00265-4.

5 Ayaz FA, Torun H, Glew RH, Bak ZD, Chuang LT, Presley JM et al., Nutrient content of carob pod (Ceratonia siliqua L.) flour prepared commercially and domestically. Plant Foods Hum Nutr 64:286-292 (2009). https://doi.org/10.1007/s11130-009-0130-3.

6 Berna A, Pérez-Gago MB, Guardiola VG, Salazar D and Mulet A, Effect of temperature on isobutyric acid loss during roasting of carob kibble. J Agric Food Chem 45:4084-4087 (1997). https://doi.org/10.1021/ jf970136p.

7 Ayaz FA, Torun H, Ayaz S, Correia PJ, Alaiz M, Sanz C et al., Determination of chemical composition of anatolian carob pod (Ceratonia siliqua L.): sugars, amino and organic acids, minerals and phenolic compounds. J Food Quality 30:1040-1055 (2007). https://doi.org/ 10.1111/j.1745-4557.2007.00176.x.

8 Youssef MKE, El-manfaloty MM and Ali HM, Assessment of proximate chemical composition, nutritional status, fatty acid composition and phenolic compounds of carob (Ceratonia siliqua L.). Food Chem 3:304-308 (2013). https://doi.org/10.5923/j.fph.20130306.06.

9 Battle M, Wollseifen HR, Mellenthin A, Haber B and Galensa R, Identification and quantification of polyphenols in carob fruits (Ceratonia siliqua L.) and derived products by HPLC-UV-ESI/MSn. J Agric Food Chem 52:3784-3791 (2004). https://doi.org/10.1021/jf030660y.

10 Battle I and Tous J, Carob Tree (Ceratonia siliqua L.). Promoting the conservation and use of underutilized and neglected crops 17. Institute of Plant Genetics and Crop Plant Research, Gatersleben/International Plant Genetic Resources Institute, Rome, pp. 1-91 (1997).

11 Sęczyk $Ł$, Świeca M and Gawlik-Dziki U, Effect of carob (Ceratonia siliqua L.) flour on the antioxidant potential, nutritional quality, and sensory characteristics of fortified durum wheat pasta. Food Chem 194:637-642 (2016). https://doi.org/10.1016/j.foodchem.2015.08 .086.

12 Galego LR and Almeida VR, Aguardentes de frutos e licores do Algarve. História, técnicas de produção e legislação. Edições Colibri, Lisboa (2007).

13 Custódio L, Fernandes E, Escapa AL, Fajardo A, Aligué R, Alberício F et al., Antioxidant and cytotoxic activities of carob tree fruit pulps are strongly influenced by gender and cultivar. J Agric Food Chem 59:7005-7012 (2011). https://doi.org/10.1021/jf200838f.

14 Cantalejo MJ, Effects of roasting temperature on the aroma components of carob (Ceratonia siliqua L.). J Agric Food Chem 45:1345-1350 (1997). https://doi.org/10.1021/jf960468e.

15 Čepo DV, Mornar A, Nigović B, Kremer D, Radanović D and Dragojević IV, Optimization of roasting conditions as an useful approach for increasing antioxidant activity of carob powder. LWT-Food Sci Technol 58:578-586 (2014). https://doi.org/10.1016/j.lwt.2014.04.004.

16 Şahin H, Topuz A, Pischetsrieder M and Özdemir F, Effect of roasting process on phenolic, antioxidant and browning properties of carob powder. Eur Food Res Technol 230:155-161 (2009). https://doi.org/ 10.1007/s00217-009-1152-7.

17 Ministry of Agriculture, Livestock and Supply, MALS. Instrução Normativa no. 13, de 30 de junho de 2005. Aprova o regulamento técnico para fixação dos padrões de identidade e qualidade para aguardente de cana e para Cachaça. Diário Oficial da União, Brasília, 2005.

18 Council Regulation (EC) No. 1493/1999 of 17 may 1999 on the common organisation of the market in wine 1179/1-84.

19 Bernardo-Gil MG, Roque R, Roseiro LB, Duarte LC, Gírio F and Esteves P, Supercritical extraction of carob kibbles (Ceratonia siliqua L.). J Supercrit Fluids 59:36-42 (2011). https://doi.org/10.1016/j.supflu .2011.08.007.

20 Kumazawa S, Taniguchi M, Suzuki $Y$, Shimura M, Kwon MS and Nakayama T, Antioxidant activity of polyphenols in carob pods. J Agric Food Chem 50:373-377 (2002). https://doi.org/10.1021/ jf010938r.

21 Otles $\mathrm{S}$ and Yalcin B, Phenolic compounds analysis of root, stalk, and leaves of nettle. Sci World J 2012:1-12 (2012). https://doi.org/10 $1100 / 2012 / 564367$

22 Yen GC and Chen HY, Antioxidant activity of various tea extracts in relation to their antimutagenicity. J Agric Food Chem 43:27-32 (1995). https://doi.org/10.1021/jf00049a007.

23 Re R, Pellegrini N, Proteggente A, Pannala A, Yang M and Rice-Evans C, Antioxidant activity applying an improved ABTS radical cation decolorization assay. Free Radic Biol Med 26:1231-1237 (1999). https://doi.org/10.1016/S0891-5849(98)00315-3.

$24 \mathrm{Yu} A N$, Li Y, Yang $\mathrm{Y}$ and $\mathrm{Yu} \mathrm{K}$, The browning kinetics of the nonenzymatic browning reaction in L-ascorbic acid/basic amino acid systems. Food Sci Technol 38:537-542 (2018). https://doi.org/10 .1590/1678-457x.08717.

25 Martins SI and Van Boekel MA, Kinetics of the glucose/glycine Maillard reaction pathways: influences of $\mathrm{pH}$ and reactant initial concentrations. Food Chem 92:437-448 (2005). https://doi.org/10.1016/j .foodchem.2004.08.013.

26 Daneshfar A, Ghaziaskar HS and Homayoun N, Solubility of gallic acid in methanol, ethanol, water, and ethyl acetate. J Chem Eng Data 53:776-778 (2008). https://doi.org/10.1021/je700633w.

27 Zhao $B$ and Hall CA, Composition and antioxidant activity of raisin extracts obtained from various solvents. Food Chem 108:511-518 (2008). https://doi.org/10.1016/j.foodchem.2007.11.003.

28 Durmaz G and Gökmen V, Determination of 5-hydroxymethyl-2-furfural and 2-furfural in oils as indicators of heat pre-treatment. Food Chem 123:912-916 (2010). https://doi.org/10.1016/j.foodchem.2010.05 .001.

$29 \mathrm{Li} \mathrm{J}, \mathrm{Xu} \mathrm{Y}$, Zhang M and Wang D, Determination of furfural and 5-hydroxymethylfurfural in biomass hydrolysate by highperformance liquid chromatography. Energy Fuel 31:13769-13774 (2017). https://doi.org/10.1021/acs.energyfuels.7b02827. 
30 Ran H, Zhang J, Gao Q, Lin Z and Bao J, Analysis of biodegradation performance of furfural and 5-hydroxymethylfurfural by Amorphotheca resinae ZN1. Biotechnol Biofuels 7:51 (2014). https://doi .org/10.1186/1754-6834-7-51.

31 Almenares-Verdecía JF, Ngoma-Presline F and Serrat-Díaz MDJ, Aspectos tecnológicos generales para la conversión a etanol de la biomasa lignocelulósica II. Tecnología Química 31:392-407 (2011). https:// doi.org/10.1590/2224-6185.2008.3.\%25x.

32 Larsson S, Palmqvist E, Hahn-Hägerdal B, Tengborg C, Stenberg K, Zacchi $G$ etal., The generation of fermentation inhibitors during dilute acid hydrolysis of softwood. Enzyme Microb Technol 24:151-159 (1999). https://doi.org/10.1016/S01410229(98)00101-X.

33 Jeurings $\mathrm{HJ}$ and Kuppers FJEM, High perfomance liquid chromatography of furfural and hydroxymethylfurfural in spirits and honey. $J$ Assoc Off Anal Chem 63:1215-1218 (1980).

34 Cortés S, Rodríguez R, Salgado JM and Domínguez JM, Comparative study between Italian and Spanish grape marc spirits in terms of major volatile compounds. Food Control 22:673-680 (2011). https:// doi.org/10.1016/j.foodcont.2010.09.006.

35 Rattanathanalerk M, Chiewchan N and Srichumpoung W, Effect of thermal processing on the quality loss of pineapple juice. J Food Eng 66:259-265 (2005). https://doi.org/10.1016/j.jfoodeng.2004.03 .016.

36 Modig T, Liden G and Taherzadeh MJ, Inhibition effects of furfural on alcohol dehydrogenase, aldehyde dehydrogenase and pyruvate dehydrogenase. Biochem J 363:769-776 (2002). https://doi.org/10 .1042/bj3630769.

37 EFSA, European Food Safety Authority, Opinion of the Scientific Panel on Food Additives, Flavourings, Processing Aids and Materi- als in contact with Food (AFC) on a request from the Commission related to Flavouring Group Evaluation 13: Furfuryl and furan derivatives with and without additional side-chain substituents and heteroatoms from chemical group 14. EFSA J 215:1-73 (2005). Available: http://www.efsa.europa.eu/sites/default/files/scientific_ output/files/main_documents/215.pdf [25 January 2018].

38 Monakhova YB and Lachenmeier DW, The margin of exposure of 5-hydroxymethylfurfural (HMF) in alcoholic beverages. Environ Health Toxicol 27:1-8 (2012). https://doi.org/10.5620/eht.2012.27 .e2012016.

39 Janzowski C, Glaab V, Samimi E, Schlatter J and Eisenbrand G, 5-Hydroxymethylfurfural: assessment of mutagenicity, DNA-damaging potential and reactivity towards cellular glutathione. Food Chem Toxicol 38:801-809 (2000). https://doi.org/10 1016/S0278-6915(00)00070-3.

40 Wolfe $\mathrm{KL}$ and Liu $\mathrm{RH}$, Cellular antioxidant activity (CAA) assay for assessing antioxidants, foods, and dietary supplements. J Agric Food Chem 55:8896-8907 (2007). https://doi.org/10.1021/jf0715166.

41 Zhou YY, Li Y and Yu AN, The effects of reactants ratios, reaction temperatures and times on Maillard reaction products of the L-ascorbic acid/L-glutamic acid system. Food Sci Technol (Campinas) 36:268-274 (2016). https://doi.org/10.1590/1678-457X.02415.

42 Martins SI, Jongen WM and Van Boekel MA, A review of Maillard reaction in food and implications to kinetic modelling. Trends Food Sci Technol 11:364-373 (2000). https://doi.org/10.1016/S09242244(01)00022-X

43 Marquez A, Serratosa MP and Merida J, Anthocyanin evolution and color changes in red grapes during their chamber drying. J Agric Food Chem 61:9908-9914 (2013). https://doi.org/10.1021/ jf402263f. 